\title{
Selected sociodemographic and clinical predictors of the clock drawing test performance in Polish community dwelling seniors
}

\author{
Wybrane socjodemograficzne i kliniczne predyktory poziomu wykonania \\ testu rysowania zegara przez polskich seniorów
}

\author{
${ }^{1}$ Faculty of Health Sciences with the Institute of Maritime and Tropical Medicine, Medical University of Gdańsk, Gdańsk, Poland \\ ${ }^{2}$ Department of Family Medicine, Faculty of Medicine, Medical University of Gdańsk, Gdańsk, Poland \\ ${ }^{3}$ Department of Cardiac Surgery, Florian Ceynowa Specialist Hospital, Wejherowo, Poland \\ ${ }^{4}$ Division of Neurological and Psychiatric Nursing, Medical University of Gdańsk, Gdańsk, Poland \\ ${ }^{5}$ Department of Neurology, St. Adalbert Hospital, Copernicus PL, Gdańsk, Poland \\ Correspondence: Emilia J. Sitek, Oddział Neurologii, Szpital Specjalistyczny św. Wojciecha, al. Jana Pawła II 50, 80-462 Gdańsk, Poland, tel.: +4858 768 46 61, fax: +48583409290, \\ e-mail: emilia.sitek@gumed.edu.pl
}

\begin{abstract}
Objectives: The clock drawing test (CDT) is a commonly used cognitive screening test. The purpose of this study was to investigate the effect of selected sociodemographic, clinical and lifestyle factors on the CDT performance in the Polish elderly population. Methods: CDT performance was assessed in 399 elderly subjects randomly selected out of all participants of a nationwide study on aging, PolSenior2, who met the inclusion criteria. CDT was scored using the Manos-Wu method. The short version of the Geriatric Depression Scale (15-item GDS) was used as a mood measuring tool. Results: Our study revealed a significant relationship between CDT performance and age. Multivariate regression analysis demonstrated also that interactions between reading newspapers and gender and between playing games and GDS score were independent predictors of an incorrect CDT. Of note, even though years of education were related to the CDT score (0-10) in the correlation analysis, education did not predict the global CDT score in the regression analysis. Conclusions: Advanced age was related to incorrect CDT performance. Engagement in some leisure activities may predict the CDT score, while global CDT performance, as assessed by the Manos-Wu method, is relatively unaffected by education.
\end{abstract}

Keywords: clock drawing test, cognitive screening, cognitive impairment, dementia, sociodemographic factors

Streszczenie Wstęp: Test rysowania zegara (TRZ) to powszechnie stosowana metoda przesiewowej oceny funkcji poznawczych. Cel: Celem pracy była analiza wpływu wybranych czynników socjodemograficznych, klinicznych i związanych ze stylem życia na wyniki TRZ wśród polskiej populacji osób starszych. Materiał i metoda: Poziom wykonania TRZ oceniono u 399 seniorów, losowo wybranych spośród wszystkich uczestników ogólnopolskiego badania PolSenior2, którzy spełnili kryteria włączenia. W badaniu zastosowano wersję TRZ Manosa i Wu. Jako narzędzie pomiaru nastroju wykorzystano skróconą wersję Geriatrycznej Skali Depresji (15-punktowa skala Geriatric Depression Scale, GDS). Wyniki: Badanie wykazało istotny związek między wynikiem TRZ a wiekiem. Analiza regresji wieloczynnikowej wykazała, że interakcje między czytaniem gazet a płcią oraz między graniem w gry a wynikiem w skali GDS mogą stanowić niezależne predyktory nieprawidłowego wykonania TRZ. Warto zauważyć, że chociaż lata nauki były powiązane z wynikiem TRZ, ocenionym metodą Manosa i Wu, $\mathrm{w}$ analizie korelacji, poziom wykształcenia nie przewidywał globalnego wyniku TRZ w analizie regresji.

Słowa kluczowe: test rysowania zegara, przesiewowa ocena funkcji poznawczych, dysfunkcje poznawcze, otępienie, czynniki socjodemograficzne 


\section{INTRODUCTION}

$\mathrm{T}$ he clock drawing test (CDT) is a widely recognised cognitive screening test used in individuals with both focal brain damage (to screen for visuospatial and/or executive dysfunction) and in patients with suspected dementia (Shulman, 2000). The CDT engages a number of cognitive domains that include verbal comprehension, semantic memory, visuospatial ability, executive function (abstract thinking, planning and inhibition) and visuomotor coordination (Hazan et al., 2018).

The CDT is easy to administer, patient-friendly, and takes very little time. The score is positively correlated with more extensive and time-consuming cognitive tests (Cullen et al., 2007; Mainland et al., 2014). Being easy to administer and score, it is appropriate for cognitive screening in the primary care settings (Mainland and Shulman, 2017). The CDT can be used either as a stand-alone tool or as part of other tests, such as the Mini-Cog scale, the Montreal Cognitive Assessment (MoCA) or Mini-Addenbrooke's Cognitive Examination (M-ACE). In clinical practice, it is frequently used with the Mini-Mental State Examination (MMSE) (Larner, 2017). There are multiple versions of the CDT, which vary in stimuli, administration and scoring. The CDT allows both quantitative and/or qualitative assessments. However, the psychometric characteristics of each scoring system are different (Mainland and Shulman, 2017). Depending on the system, the patient may be asked either to draw a clock face or fill it in; in most of the CDT variants the patient is also asked to draw the hands that show a given time. Thus, researchers and clinicians who use the CDT are faced with the dilemma of choosing the best administration procedure and scoring system (Spenciere et al., 2017; Wójcik and Szczechowiak, 2019).

Cognitive performance in the elderly is affected by multiple factors. Unfavourable demographic and socioeconomic status as well as lifestyle are known risk factors for cognitive impairment (Lynch et al., 1997), but also potential confounders affecting performance at neuropsychological testing (Strauss et al., 2006). The available data on the influence of sociodemographic and clinical characteristics, including age, sex, education, income status, place of residence, presence of depression and motor discoordination, on CDT performance is inconsistent. The inconsistencies in the literature are likely to stem from the fact that there are

\begin{tabular}{|l|c|c|c|}
\hline \multirow{2}{*}{ Age [years] } & \multicolumn{2}{|c|}{ Gender } & \multirow{2}{*}{ Total } \\
\cline { 2 - 3 } & Men & Women & \\
\hline $60-64$ & 34 & 34 & 68 \\
\hline $65-69$ & 34 & 34 & 68 \\
\hline $70-74$ & 33 & 34 & 67 \\
\hline $75-79$ & 34 & 34 & 68 \\
\hline $80-84$ & 32 & 32 & 64 \\
\hline $85-89$ & 32 & 32 & 64 \\
\hline Total & 199 & 200 & 399 \\
\hline
\end{tabular}

Tab. 1. Age distribution of study participants more than 10 popular CDT procedures and scoring systems (Mainland and Shulman, 2017).

Considering the clinical utility of CDT and its potential applicability in primary care, we aimed to evaluate the sociodemographic and lifestyle predictors of CDT performance based on the data from the PolSenior2 project. Additionally, we set out to determine if rural residence and depressive symptoms are associated with an increased risk of dementia.

\section{MATERIALS AND METHODS}

\section{Study design and setting}

PolSenior2 was a second Polish multidisciplinary research project, conducted between 2016 and 2020 (started 10 years after PolSenior1) (Bledowski et al., 2011), focused on assessing the health status of elderly people and their needs. The aim of the project was to define the health status and socioeconomic situation of old and very-old adults in Poland as well as to find trends in health, health-related behaviours, and social situation of seniors.

In the PolSenior2 project, a total of 3,057 women and 2,930 men, aged 60 years and older, were included. Participants were selected through a multistage draw, so as to obtain a representative group. The selection was performed independently in seven roughly equally sized $(n=850)$ age cohorts (60-64, 65-69, 70-74, 75-79, 80-84, 85-89, and 90+ years). Overall, 5,987 subjects underwent the questionnaire parts of the survey. A detailed description of the study design has already been presented elsewhere (Wierucki et al., 2020).

\section{Study procedure}

Sociodemographic data were obtained using the PolSenior2 questionnaire (Wierucki et al., 2020). All respondents were asked about their education level, marital status, living situation, economic status, and selected clinical aspects (being under the care of a specialist, memory problems, falls, arterial hypertension, arrhythmia, diabetes).

Additionally, selected health behaviours - including subjective physical activity level and leisure time activities, presence of support from relatives and friends - were used in the analysis. Data about physical, social and leisure time activities like reading newspapers or books, going to the theatres or cinemas, etc. was obtained from the section of the PolSenior2 questionnaire entitled "Physical activity and leisure."

\section{Participant selection}

The current study sample consisted of 400 subjects ( $200 \mathrm{ru}$ ral dwellers and 200 urban dwellers), randomly selected amongst the PolSenior2 project participants, who met the inclusion criteria. The same number of cases was selected from each age subgroup from the original study cohort, taking into account the equal distribution of sex and place 


\begin{tabular}{|c|c|c|c|c|c|c|c|}
\hline \multirow{2}{*}{ Characteristics } & \multicolumn{2}{|c|}{ Total } & \multicolumn{2}{|c|}{$\begin{array}{c}\text { Urban } \\
\text { dwellers }\end{array}$} & \multicolumn{2}{|c|}{$\begin{array}{c}\text { Rural } \\
\text { dwellers }\end{array}$} & \multirow{2}{*}{$p^{* *}$} \\
\hline & $\begin{array}{c}\text { Num- } \\
\text { ber }\end{array}$ & $\% *$ & $\begin{array}{l}\text { Num- } \\
\text { ber }\end{array}$ & \%* & $\begin{array}{c}\text { Num- } \\
\text { ber }\end{array}$ & $\% *$ & \\
\hline \multicolumn{8}{|l|}{ Gender $\left(n=399^{* * *}\right)$} \\
\hline Women & 200 & 50.13 & 100 & 25.06 & 100 & 25.06 & \multirow{2}{*}{0.96} \\
\hline Men & 199 & 49.87 & 99 & 24.81 & 100 & 25.06 & \\
\hline \multicolumn{8}{|l|}{ Age cohort $(n=399)$} \\
\hline $60-64$ & 68 & 17.04 & 34 & 8.52 & 34 & 8.52 & \\
\hline $65-69$ & 67 & 16.79 & 33 & 8.27 & 34 & 8.52 & \\
\hline $70-74$ & 68 & 17.04 & 34 & 8.52 & 34 & 8.52 & \\
\hline $75-79$ & 64 & 16.04 & 32 & 8.02 & 32 & 8.02 & \\
\hline $80-84$ & 68 & 17.04 & 34 & 8.52 & 34 & 8.52 & \\
\hline $85-89$ & 64 & 16.04 & 32 & 8.02 & 32 & 8.02 & \\
\hline \multicolumn{8}{|c|}{ Education level $(n=399)$} \\
\hline $\begin{array}{l}\text { Lack of education } \\
\text { or incomplete } \\
\text { primary school }\end{array}$ & 15 & 3.76 & 5 & 1.25 & 10 & 2.51 & \multirow{4}{*}{$<0.001$} \\
\hline Primary school & 120 & 30.08 & 41 & 10.28 & 79 & 19.80 & \\
\hline Secondary school & 219 & 54.89 & 126 & 31.58 & 93 & 23.31 & \\
\hline Higher education & 45 & 11.28 & 27 & 6.77 & 18 & 4.51 & \\
\hline \multicolumn{8}{|c|}{ Present marital status $(n=397)$} \\
\hline Never married & 10 & 2.52 & 5 & 1.26 & 5 & 1.26 & \multirow{4}{*}{0.747} \\
\hline Married & 251 & 63.22 & 122 & 30.73 & 129 & 32.49 & \\
\hline Widowed & 120 & 30.23 & 61 & 15.37 & 59 & 14.86 & \\
\hline Divorced & 16 & 4.03 & 10 & 2.52 & 6 & 1.51 & \\
\hline \multicolumn{8}{|c|}{ Living situation $(n=398)$} \\
\hline Alone & 80 & 20.10 & 49 & 12.31 & 31 & 7.79 & \multirow{2}{*}{0.021} \\
\hline With family & 318 & 79.90 & 149 & 37.44 & 169 & 42.46 & \\
\hline \multicolumn{8}{|c|}{ Economic status $(n=396)$} \\
\hline $\begin{array}{l}\text { Enough money for } \\
\text { all needs without } \\
\text { savings }\end{array}$ & 67 & 16.92 & 36 & 9.09 & 31 & 7.83 & \multirow{5}{*}{0.131} \\
\hline $\begin{array}{l}\text { Enough money for } \\
\text { all needs but with } \\
\text { savings }\end{array}$ & 213 & 53.79 & 115 & 29.04 & 98 & 24.75 & \\
\hline $\begin{array}{l}\text { Enough money but } \\
\text { not for all needs }\end{array}$ & 87 & 21.97 & 33 & 8.33 & 54 & 13.64 & \\
\hline $\begin{array}{l}\text { Enough money only } \\
\text { for the cheapest food }\end{array}$ & 20 & 5.05 & 9 & 2.27 & 11 & 2.78 & \\
\hline $\begin{array}{l}\text { Not enough money } \\
\text { even for the cheap- } \\
\text { est food and clothing }\end{array}$ & 8 & 2.02 & 3 & 0.76 & 5 & 1.26 & \\
\hline
\end{tabular}

\begin{tabular}{|c|c|c|c|c|c|c|c|}
\hline \multirow{2}{*}{ Characteristics } & \multicolumn{2}{|c|}{ Total } & \multicolumn{2}{|c|}{$\begin{array}{c}\text { Urban } \\
\text { dwellers }\end{array}$} & \multicolumn{2}{|c|}{$\begin{array}{c}\text { Rural } \\
\text { dwellers }\end{array}$} & \multirow{2}{*}{$p^{* *}$} \\
\hline & \begin{tabular}{|c|}
$\begin{array}{c}\text { Num- } \\
\text { ber }\end{array}$ \\
\end{tabular} & $\% *$ & $\begin{array}{c}\text { Num- } \\
\text { ber }\end{array}$ & $\% *$ & $\begin{array}{c}\text { Num- } \\
\text { ber }\end{array}$ & \%* & \\
\hline \multicolumn{8}{|l|}{ Medical aspects } \\
\hline $\begin{array}{l}\text { Under the care } \\
\text { of a specialist during } \\
\text { the last } 5 \text { years }\end{array}$ & $\begin{array}{l}274 \\
(n= \\
391)\end{array}$ & 68.67 & 142 & 35.59 & 132 & 33.08 & 0.252 \\
\hline $\begin{array}{l}\text { Reporting memory } \\
\text { problems }\end{array}$ & $\begin{array}{l}170 \\
(n= \\
391)\end{array}$ & 43.48 & 84 & 21.48 & 86 & 21.99 & 0.943 \\
\hline $\begin{array}{l}\text { Falls during the last } \\
12 \text { months }\end{array}$ & $\begin{array}{c}58 \\
(n= \\
394)\end{array}$ & 14.72 & 29 & 7.36 & 29 & 7.36 & 0.933 \\
\hline $\begin{array}{l}\text { Arterial } \\
\text { hypertension }\end{array}$ & $\begin{array}{l}264 \\
(n= \\
396) \\
\end{array}$ & 66.67 & 124 & 31.31 & 140 & 35.35 & 0.088 \\
\hline Arrhythmia & $\begin{array}{l}103 \\
(n= \\
382)\end{array}$ & 26.96 & 50 & 13.09 & 53 & 13.87 & 0.729 \\
\hline Diabetes & $\begin{array}{c}92 \\
(n= \\
397)\end{array}$ & 23.17 & 42 & 10.58 & 50 & 12.59 & 0.385 \\
\hline \multicolumn{8}{|c|}{ Everyday life: support and lifestyle $(n=399)$} \\
\hline $\begin{array}{l}\text { Support from } \\
\text { relatives and friends }\end{array}$ & 378 & 94.97 & 184 & 46.23 & 194 & 48.74 & 0.063 \\
\hline Physically active & 313 & 78.64 & 153 & 38.44 & 160 & 40.20 & 0.392 \\
\hline Socially active & 363 & 91.44 & 179 & 45.09 & 184 & 46.35 & 0.464 \\
\hline Reading newspapers & 310 & 77.89 & 157 & 39.45 & 153 & 38.44 & 0.629 \\
\hline Reading books & 195 & 48.99 & 105 & 26.38 & 90 & 22.61 & 0.133 \\
\hline $\begin{array}{l}\text { Going out to the } \\
\text { theatre/concerts }\end{array}$ & 54 & 13.57 & 36 & 9.05 & 18 & 4.52 & 0.008 \\
\hline $\begin{array}{l}\text { Going out } \\
\text { to the cinema }\end{array}$ & 82 & 20.60 & 56 & 14.07 & 26 & 6.53 & $<0.001$ \\
\hline $\begin{array}{l}\text { Playing games } \\
\text { (cards, chess etc.) }\end{array}$ & 47 & 11.84 & 25 & 6.30 & 22 & 5.54 & 0.628 \\
\hline \multicolumn{8}{|c|}{$\begin{array}{l}\text { *\% of the group analysed in a given component. } \\
\text { ** Chi-squared statistics. } \\
\text { *** Due to some missing data for each variable the number of participants } \\
\text { included in the analysis, for whom data was complete, is specified in brackets. }\end{array}$} \\
\hline
\end{tabular}

Tab. 2. Distribution of sociodemographic characteristics of study participants according to the place of residence

of residence (rural vs. urban). The strict exclusion criteria were: (1) age >90 years; (2) history of stroke; (3) no CDT performance; (4) mixed urban-rural place of residence; (5) visual impairment making it impossible for the participant to watch TV, and (6) being institutionalised.

Because some of the crucial data was missing in one of the previously selected study participants, ultimately measurements from 399 respondents were included in the present analysis. The selected group was proportionately distributed according to age and sex (Tab. 1). The median age was 74 years. About $37 \%$ of the participants were unmarried, including widows/widowers, those who were divorced or separated from their spouses, as well as those who never married, and there was no difference in this respect between urban and rural dwellers. Almost one fifth of all respondents lived alone. An education level higher than secondary was declared only by $11 \%$ of the individuals. Urban dwellers were better educated than rural residents. $7 \%$ of all studied subjects declared that they could afford buying only the cheapest food/clothing or not even that, which was considered as self-reported poverty (with no difference identified between urban and rural dwellers). Respondents living in the urban areas more often declared going out to the theatre/ concerts and to the cinema than those living in the rural 


\begin{tabular}{|l|c|c|c|}
\hline & $\begin{array}{c}\text { Participants with incorrect CDT } \\
\text { performance } \\
\boldsymbol{n}=\mathbf{2 0 2} \\
\text { [median (IQR)] }\end{array}$ & $\begin{array}{c}\text { Participants with correct CDT } \\
\text { performance } \\
\boldsymbol{n}=197 \\
\text { [median (IQR)] }\end{array}$ & $\begin{array}{c}\text { Mann-Whitney U test - } \\
\boldsymbol{p} \text { level }\end{array}$ \\
\hline Age [years] & $78(69-84)$ & $71(65-77)$ & $<0.001$ \\
\hline Years of education & $9(7-12)$ & $11(8-13)$ & $<0.001$ \\
\hline GDS (max. 15) & $4(2-7)$ & $3(2-5)$ & 0.0036 \\
\hline MMSE (max. 30) & 25 (22-28) & $28(26-29)$ & $<0.001$ \\
\hline CDT - clock drawing test; IQR - interquartile range; GDS - Geriatric Depression Scale; MMSE - Mini-Mental State Examination. \\
\hline
\end{tabular}

Tab. 3. CDT performance in the context of selected demographic and clinical variables

areas. However, there was no significant difference in terms of playing games, reading newspapers and reading books between urban and rural dwellers. $95 \%$ of all participants declared having support from relatives and friends. Tab. 2 shows the social, economic and lifestyle characteristics of the studied group.

\section{Cognitive and mood assessment}

The cognitive status and mood were assessed by specially trained nurses during a home visit as a part of the PolSenior2 assessment procedures.

The participants were given a predrawn circle with a dot in the middle (on an A4 sheet of paper) and were asked to fill in the clock with numbers and set the hands at ten minutes past eleven. Each page of the CDT was scanned into a digital format at 300 dpi using Canon PIXMA MG5450 with colour confidence small greyscale and colour separation guide (monitoring colour calibration). The scan files were imported by CorelDRAW software, where a circle template divided into eight equal parts (projected in CorelDRAW) was used to facilitate the evaluation of CDT performance. The CDT was assessed using the Manos-Wu scoring method (Manos and Wu, 1994).

According to the Manos-Wu scoring system, one point was given for each of the numbers falling into its proper zone of the circle: $1,2,4,5,7,8,10$, and 11 . One point was given to the short hand pointing at number eleven, one point was given to the long hand pointing at number two. The final score ranged from 0 to 10 [8 (numbers) +1 (short hand) +1 (long hand $)=10$ ]. Raw scores were used in the correlation analysis. For the purposes of the logistic regression

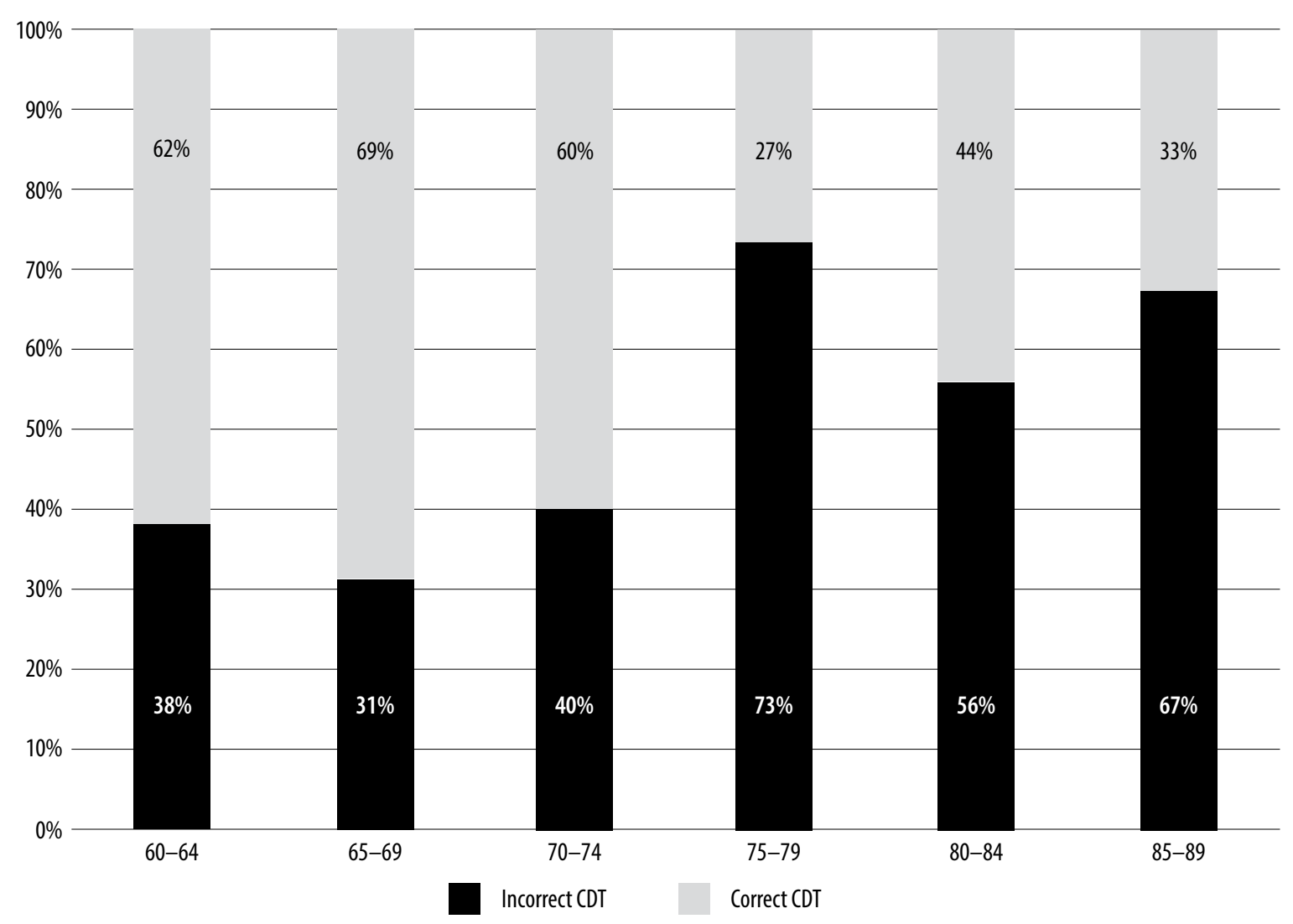




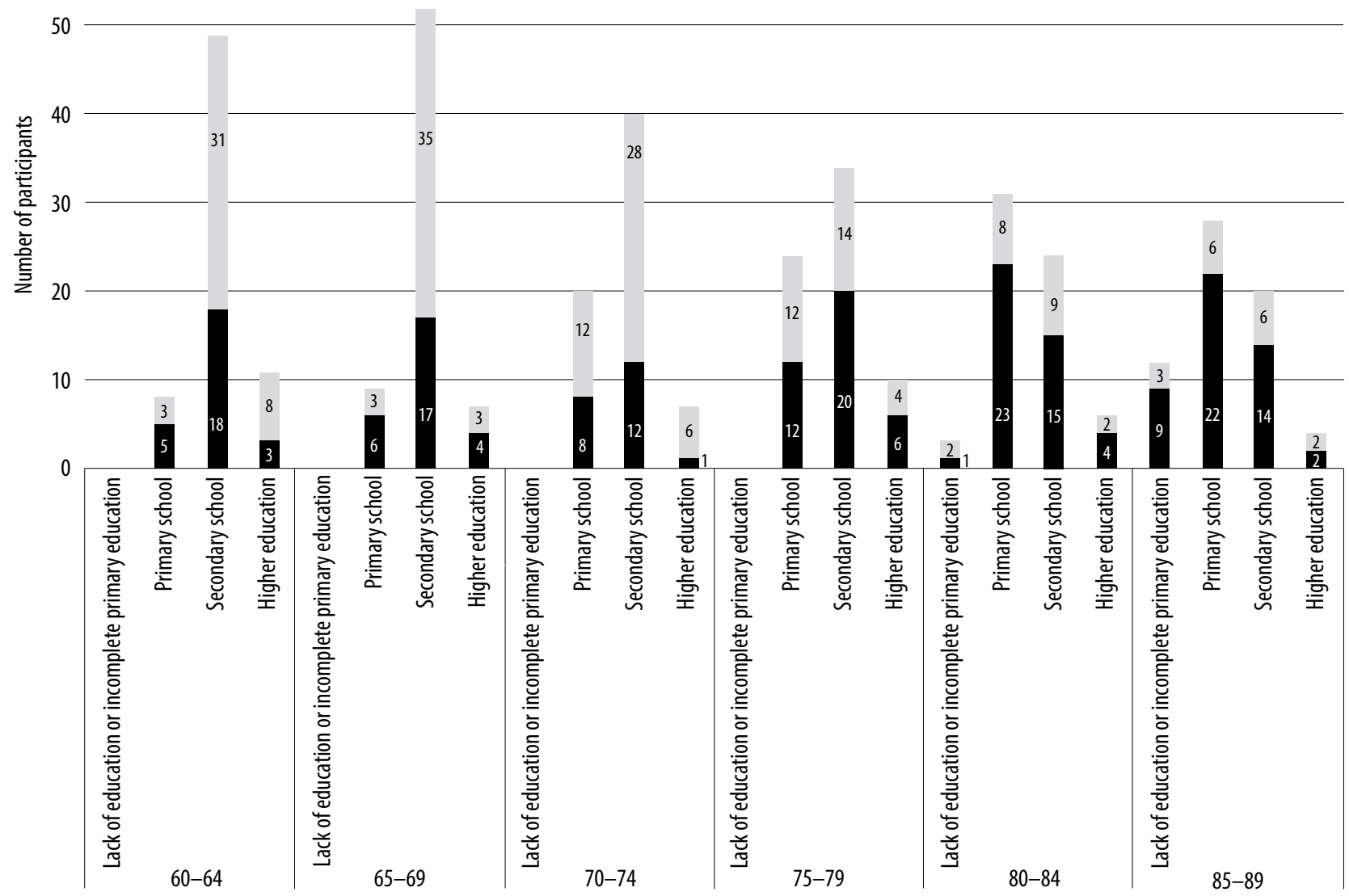

Fig. 2. Distribution of correct vs. incorrect CDT performance in six age groups divided according to the education level

analysis, the cut-off score was determined as <8 (0-7: incorrect, probably demented; 8-10: correct CDT, probably not demented) (Manos, 1999; Manos and $\mathrm{Wu}, 1994$ ). Manos and $\mathrm{Wu}$ found that a cut-off score of 7 out of 10 identified adequately $76 \%$ of patients with dementia and $78 \%$ of control patients. A later study using the same test attempted to identify patients with mild Alzheimer disease (i.e. those with MMSE >23) among consecutive ambulatory patients. The author reported a sensitivity of $71 \%$, compared to $76 \%$ for the original study that included patients with a mean MMSE score of 20 (Manos, 1999).

In addition to the CDT, cognitive function was assessed using the MMSE (Folstein et al., 1975). The screening assessment for mood disorders was performed with the Geriatric Depression Scale (15-item GDS, Short Form). Depression was suspected if the participants scored $\geq 6$ out of 15 (Sheikh and Yesavage, 1986).

\section{Statistical analysis}

Statistical analysis was performed with STATISTICA 13.3 software (StatSoft, Poland). Intergroup differences were assessed using chi-square tests, Mann-Whitney $U$ test or Kruskal-Wallis $H$ test, depending on the number of groups being compared, variable characteristics, and data distribution. Correlation analyses were performed using Spearman's rank correlation coefficient. To identify the variables to enter in the regression models, a correlation analysis was performed for quantitative variables, and intergroup comparisons were performed for qualitative variables. Multivariate stepwise backward logistic regression analysis was carried out to analyse the predictors of incorrect CDT performance. A two-stage approach was used to build regression models. Initially, univariate regression analyses were used to screen for variables likely to be associated with correct CDT performance $(p<0.10)$.

Variables such as age, gender, years of education, place of residence (urban vs. rural), support from relatives (yes/ no), physical activity (yes/no), other leisure time activities (yes/no): reading newspapers/magazines; reading books; going out to the theatre or concerts; going out to the cinema; visiting friends or family/relatives; playing games (cards and chess), and GDS score were considered as possible predictors of CDT performance. Medical aspects could 


\begin{tabular}{|c|c|c|c|c|c|}
\hline \multirow[t]{2}{*}{ Variable } & \multicolumn{5}{|c|}{ Correlation } \\
\hline & CDT & Age & Years of education & GDS & MMSE \\
\hline CDT & & $-0.26 * * *$ & $0.21^{* * * *}$ & $-0.13^{* *}$ & $0.33^{* * * *}$ \\
\hline Age & $-0.26^{* * *}$ & & $-0.47^{* * *}$ & $0.24^{* * * *}$ & $-0.46^{* * *}$ \\
\hline Years of education & $0.21^{* * * *}$ & $-0.47^{* * * *}$ & & $-0.23^{* * *}$ & $0.39^{* * *}$ \\
\hline GDS & $-0.13^{* *}$ & $0.24^{* * * *}$ & $-0.23^{* * *}$ & & $-0.28^{* * *}$ \\
\hline MMSE & $0.33^{* * *}$ & $-0.46^{* * * *}$ & $0.39^{* * * *}$ & $-0.28^{* * *}$ & \\
\hline
\end{tabular}

Tab. 4. Correlation analysis of CDT performance and selected demographic and clinical variables

not be included in the regression models due to missing data (Tab. 2). Then, possible interactions among the selected variables were identified. Finally, the variables identified in univariate analyses and their interactions were entered into a multivariate backward stepwise regression model. The results are presented with unstandardised coefficients, $p$ values, and odds ratios with $95 \%$ confidence intervals (95\% CIs). The significance level was set at $p<0.05$, unless specified otherwise (in the case of exploratory analyses). Nagelkerke $R^{2}$ was used as a measure of goodness of fit.

\section{RESULTS}

Among 399 participants, 202 (50.63\% of the study group, 103 men and 99 women) performed the CDT incorrectly (scored $<8$ out of 10 using the Manos-Wu method). Incorrect CDT performance was noted in the majority of the participants aged over 75 . The individuals who performed the CDT correctly were significantly younger (Fig. 1) and better educated (Fig. 2) than those who performed it incorrectly. The MMSE score was higher, and the

\begin{tabular}{|c|c|c|c|c|c|}
\hline \multirow{2}{*}{ Explanatory variables (predictors) } & \multirow{2}{*}{$\beta$} & \multirow{2}{*}{$\mathbf{O R}$} & \multicolumn{2}{|c|}{$95 \% \mathrm{Cl}$} & \multirow{2}{*}{$p$} \\
\hline & & & Lower & Upper & \\
\hline \multicolumn{6}{|l|}{ Gender* } \\
\hline Woman & 0.045 & 1.046 & 0.860 & 1.273 & 0.652 \\
\hline Age & 0.061 & 0.917 & 0.868 & 0.970 & $<0.001$ \\
\hline Years of education & 0.102 & 1.108 & 1.048 & 1.171 & $<0.001$ \\
\hline \multicolumn{6}{|l|}{ Place of residence } \\
\hline Urban & 0.075 & 1.078 & 0.886 & 1.312 & 0.453 \\
\hline GDS score & -0.111 & 0.895 & 0.838 & 0.955 & $<0.001$ \\
\hline \multicolumn{6}{|l|}{ Everyday life } \\
\hline \multicolumn{6}{|l|}{ Support from relatives and friends } \\
\hline Yes & 0.203 & 1.225 & 0.774 & 1.937 & 0.386 \\
\hline \multicolumn{6}{|l|}{ Physically active } \\
\hline Yes & 0.469 & 1.598 & 1.240 & 2.060 & $<0.001$ \\
\hline \multicolumn{6}{|l|}{ Socially active } \\
\hline Yes & 0.383 & 1.466 & 1.009 & 2.130 & 0.045 \\
\hline \multicolumn{6}{|l|}{ Reading newspapers/magazines } \\
\hline Yes & 0.216 & 1.241 & 0.977 & 1.578 & 0.077 \\
\hline \multicolumn{6}{|l|}{ Reading books } \\
\hline Yes & 0.242 & 1.274 & 1.045 & 1.553 & 0.017 \\
\hline \multicolumn{6}{|l|}{ Going out to the theatre/concert } \\
\hline Yes & 0.324 & 1.382 & 1.028 & 1.858 & 0.032 \\
\hline \multicolumn{6}{|l|}{ Going out to the cinema } \\
\hline Yes & 0.299 & 1.349 & 1.053 & 1.728 & 0.018 \\
\hline \multicolumn{6}{|l|}{ Playing games } \\
\hline Yes & 0.341 & 1.407 & 1.026 & 1.928 & 0.034 \\
\hline
\end{tabular}




\begin{tabular}{|c|c|c|c|c|c|c|}
\hline \multirow{2}{*}{ Explanatory variables (predictors) } & \multirow{2}{*}{$\beta$} & \multirow{2}{*}{ OR } & \multicolumn{2}{|c|}{$95 \% \mathrm{Cl}$} & \multirow{2}{*}{$p$} & \multirow{2}{*}{$R^{2}$ Nagelkerke } \\
\hline & & & Lower & Upper & & \\
\hline Age & 0.061 & 0.917 & 0.868 & 0.970 & 0.000 & \multirow{3}{*}{0.151} \\
\hline Gender reading newspapers & -0.234 & 1.063 & 1.035 & 1.092 & 0.031 & \\
\hline GDS playing games & -0.086 & 0.008 & 0.001 & 0.059 & 0.002 & \\
\hline
\end{tabular}

Tab. 6. Final model of the multiple stepwise backward logistic regression analysis explaining incorrect CDT performance (OR and 95\% CI)

GDS score was lower in the group of respondents with correct CDT than with incorrect CDT performance (Tab. 3).

There was a weak negative correlation between the CDT score and age, as well as between the CDT and GDS scores. The CDT score was also positively correlated with the duration of education and with MMSE score, but the strength of the relationship was weak (Tab. 4).

Logistic regression analysis revealed three predictors of incorrect CDT performance. Apart from age, the interaction between gender and reading newspapers as well as between GDS score and playing games predicted incorrect CDT performance. However, the final model explained only about $15 \%$ of the variance (Tabs. 5 and 6).

Of note, the duration of education was not included in the final model. As shown in Fig. 3, women reading newspapers were more likely to perform the CDT correctly. As demonstrated in Fig. 4, those with higher GDS scores and not playing games were more likely to perform the CDT incorrectly.

The participants who performed the CDT correctly were significantly more physically and socially active. There was no significant difference in terms of support from relatives and friends. However, the participants with incorrect CDT performance more frequently reported not going out to the cinema or to the theatre/concerts than participants with correct CDT. Also respondents with incorrect CDT results reported playing games significantly less than the ones with correct CDT performance, albeit only $12 \%$ of the study population declared playing games. The participants with incorrect CDT performance reported reading fewer books, but not newspapers, than those with correct CDT performance. Of note, since in the logistic regression analysis the interaction between reading newspapers and gender was one of the predictors of incorrect CDT performance,
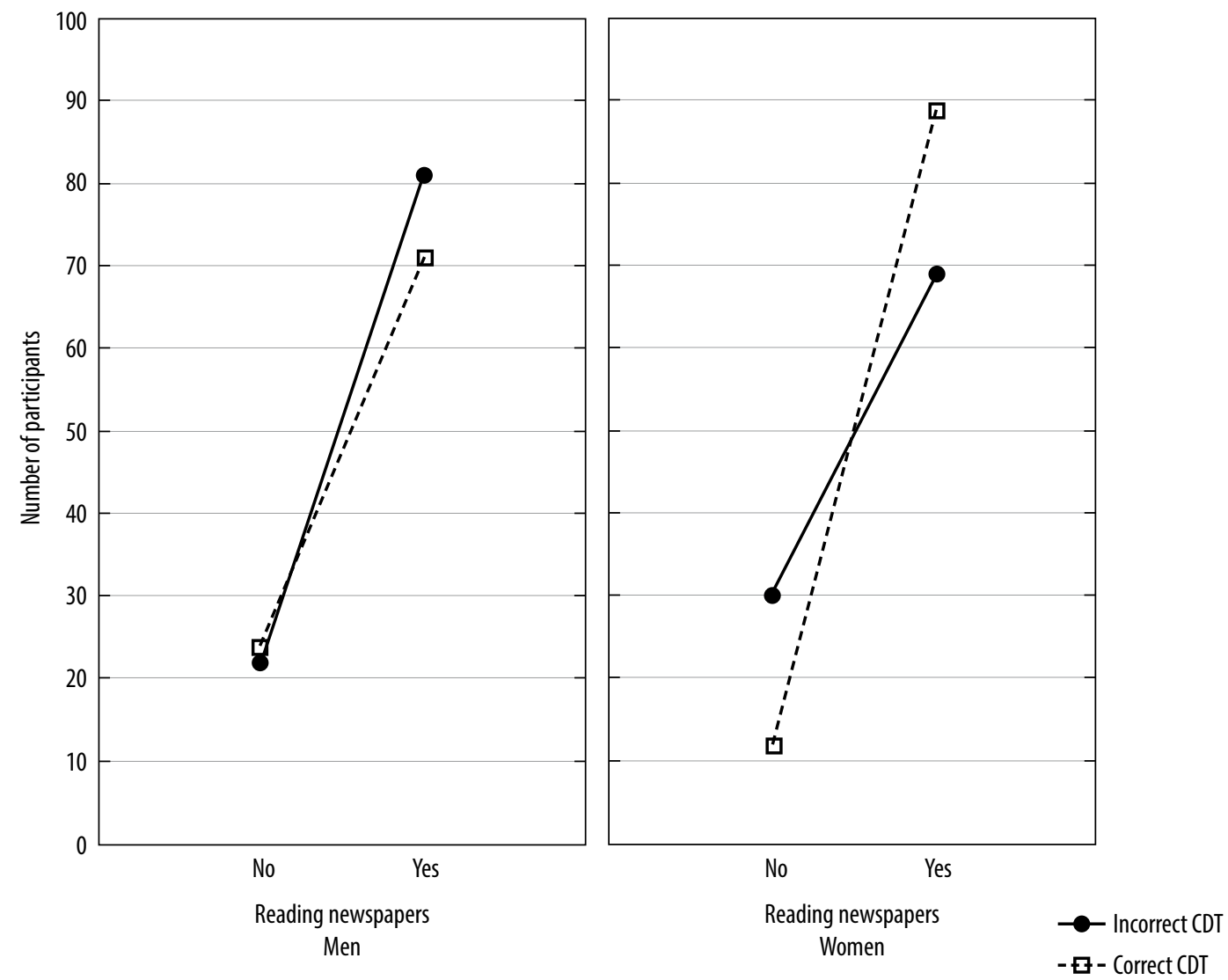

Fig. 3. Interaction between gender and reading newspapers with regard to CDT performance 


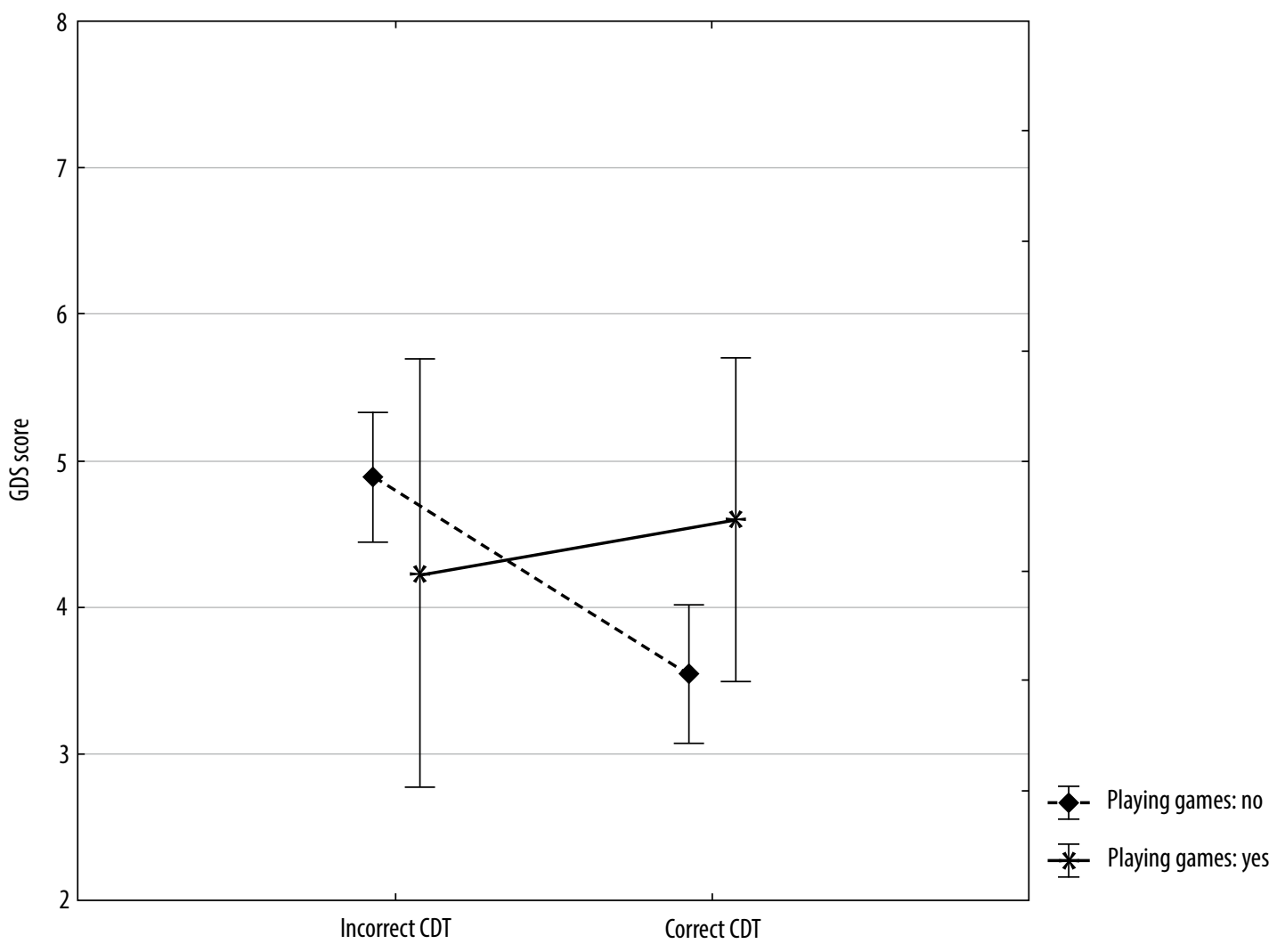

Fig. 4. Interaction between mood (GDS score) and playing games with regard to CDT performance

we conducted an additional intergroup comparison demonstrating that women read more newspapers than men (Tabs. 7 and 8).

\section{DISCUSSION}

The purpose of this study was to examine the sociodemographic, clinical and lifestyle factors affecting the global CDT performance among Polish seniors, aged 60-89 years, using the Manos-Wu scoring method (Manos and Wu, 1994). In accordance with previous studies (Mainland and Shulman, 2017), older age predicted incorrect CDT performance. Of note, more than half of the participants aged over 75 included in this analysis performed the CDT incorrectly. It highlights the necessity to monitor cognitive function in the elderly as part of primary care assessment procedures (Bradford et al., 2009).

Our results show that the effect of education on CDT performance may vary according to the scoring method used. In our study, the duration of education correlated significantly with CDT performance. However, in the multivariate regression model, education was not identified as an independent predictor of incorrect CDT performance. In the literature, there is conflicting evidence on the significance of education. For instance, Caffarra et al. (2011) observed that the CDT was unaffected by age or years of education. Yamamoto et al. (2004) also found that the CDT was unaffected by age or years of education, whereas von Gunten et al. (2008) confirmed

8 the worsening of CDT performance with increasing age and decreasing education. Ainslie and Murden (1993) and later Kim and Chey (2010) also showed that less-educated healthy elderly subjects performed the CDT significantly worse than well-educated controls. The differences between those findings may arise from differences in the populations studied as well as dissimilarities in the statistical analyses, and different scoring systems. Furthermore, there may be interactions between sociodemographic variables which impact on CDT performance with respect to the method of administration and/or procedure. Emek-Savaş et al. (2018) reported that the CDT scores of individuals assessed by two different scoring methods (including the same scoring method as that used in our study) were affected by the level of education. They found that the subjects with the length of education $<5$ years scored worse than those with at least high school education. In their study, the CDT total scores obtained using the ManosWu method differed significantly between education groups. Are CDT scores obtained using the Manos-Wu scoring method independent of education? The discrepancy between the correlation analysis and regression analysis may suggest that other factors, including the cognitive reserve, need to be considered when determining its predictive value. Future research might further scrutinise the role of such factors. Nevertheless, our findings may indicate that the CDT global score (correct vs. incorrect) according to the Manos-Wu scoring system is relatively independent of education and thus can be recommended for use even in poorly educated individuals. 


\begin{tabular}{|c|c|c|c|}
\hline & $\begin{array}{c}\text { Incorrect CDT } \\
(\%)\end{array}$ & $\begin{array}{c}\text { Correct CDT } \\
(\%)\end{array}$ & $\begin{array}{c}\text { Chi-squared } \\
\text { statistics }\end{array}$ \\
\hline \multicolumn{4}{|l|}{ Gender } \\
\hline Woman & 24.81 & 25.31 & \multirow{2}{*}{0.652} \\
\hline Man & 25.81 & 24.06 & \\
\hline \multicolumn{4}{|c|}{ Probable depression according to GDS cut-off score ( $\geq 6)$ : } \\
\hline Yes & 63 & 37 & \multirow{2}{*}{0.002} \\
\hline No & 46 & 54 & \\
\hline \multicolumn{4}{|c|}{ Everyday life } \\
\hline \multicolumn{4}{|c|}{ Support from relatives and friends } \\
\hline Yes & 47.49 & 47.49 & \multirow{2}{*}{0.383} \\
\hline No & 3.02 & 2.01 & \\
\hline \multicolumn{4}{|c|}{ Physically active } \\
\hline Yes & 35.93 & 42.71 & \multirow{2}{*}{$<0.001$} \\
\hline No & 14.57 & 6.78 & \\
\hline \multicolumn{4}{|c|}{ Socially active } \\
\hline Yes & 45.09 & 46.35 & \multirow{2}{*}{0.041} \\
\hline No & 5.79 & 2.77 & \\
\hline \multicolumn{4}{|c|}{ Reading newspapers/magazines } \\
\hline Yes & 37.69 & 40.20 & \multirow{2}{*}{0.076} \\
\hline No & 13.07 & 9.05 & \\
\hline \multicolumn{4}{|c|}{ Reading books } \\
\hline Yes & 21.86 & 27.14 & \multirow{2}{*}{0.016} \\
\hline No & 28.89 & 22.11 & \\
\hline \multicolumn{4}{|c|}{ Going out to the theatre/concerts } \\
\hline Yes & 5.03 & 8.54 & \multirow{2}{*}{0.030} \\
\hline No & 45.73 & 40.70 & \\
\hline \multicolumn{4}{|c|}{ Going out to the cinema } \\
\hline Yes & 8.04 & 12.56 & \multirow{2}{*}{0.017} \\
\hline No & 42.71 & 36.68 & \\
\hline \multicolumn{4}{|c|}{ Playing games } \\
\hline Yes & 4.28 & 7.56 & \multirow{2}{*}{0.032} \\
\hline No & 46.60 & 41.56 & \\
\hline \multicolumn{4}{|c|}{ CDT - clock drawing test; GDS - Geriatric Depression Scale. } \\
\hline
\end{tabular}

Tab. 7. CDT performance in the context of qualitative variables included in the final logistic regression model

Our findings showed that the place of residence (urban vs. rural) had no predictive effect of the CDT performance. However, in the PolSenior 1 survey, cognitive impairment diagnosed on the basis of MMSE was observed more often in rural than urban areas (Klich-Rączka et al., 2012). Therefore, caution must be employed when interpreting all tests, primarily considering the fact that in the urban environment there is wider access to intellectually stimulating activities (e.g. literature, newspapers, cinemas, theatres), and people living in these areas may exhibit more interest in political and economic issues. In turn, rural areas offer fewer activities stimulating cognitive function.

The results of our study show the importance of lifestyle aspects including mental activities considered to protect the

\begin{tabular}{|c|c|c|c|}
\hline & Women (\%) & Men (\%) & $\begin{array}{l}\text { Chi-squared } \\
\text { statistics }\end{array}$ \\
\hline \multicolumn{4}{|c|}{ Reading newspapers/magazines } \\
\hline Yes & 39.70 & 38.19 & \multirow{2}{*}{0.592} \\
\hline No & 10.55 & 11.56 & \\
\hline \multicolumn{4}{|c|}{ Reading books } \\
\hline Yes & 29.90 & 19.10 & \multirow{2}{*}{$<0.001$} \\
\hline No & 20.35 & 30.65 & \\
\hline
\end{tabular}

Tab. 8. Reading books and newspapers according to gender

aging brain. We found that the engagement in reading newspapers associated with gender and engagement in playing games associated with the GDS score might be important predictors of the CDT performance. Women not reading newspapers were more likely to present with incorrect CDT performance. We did not analyse the types of newspapers read, changes in reading patterns in comparison to previous decades or time spent reading, so we cannot provide a direct practice recommendation based on our findings.

Among the individuals with incorrect CDT performance, those that did not play games were more likely to have higher GDS scores. Our results do not allow any causal interpretation of this pattern of results. It is possible that the individuals who are less depressed are more motivated to play games. However, it is equally plausible that playing games may be a protective factor against both depression and cognitive impairment. Our finding are consistent with the literature that indicates a relationship between participation in leisure activities and better mood in the elderly (Fine, 2001). Board games may be helpful in the prevention of cognitive impairment (Noda et al., 2019).

Many studies support the so-called cognitive reserve hypothesis of mental functioning. The risk of developing dementia is significantly lower among people who report doing daily intellectual activities than individuals who do them less often or not at all. This lower risk appears to be independent of any interventions such as following a healthy diet and getting regular exercise (Hughes et al., 2010; Lee et al., 2018; Verghese et al., 2003).

Almeida-Meza et al. (2021) followed up 8,030 participants above 50 years old from the English Longitudinal Study of Ageing in order to explore intellectual and social leisure activities in relation to dementia. They found that engagement in various cognitive and social type of leisure activities appeared to be protective against dementia. They observed noteworthy effects for having hobbies, being a member of a sports club, and reading magazines. In their study, the women who regularly read a newspaper had a 35 percent lower risk of dementia, which is consistent with our results. Similarly in our study, in the multivariate logistic regression analysis, the women who declared reading newspapers performed better in the CDT.

We found that playing games had a significant impact on CDT performance too, but physical activity did not predict the CDT score. This supports the crucial role of intellectual 
activity in promoting brain health. The correlation between better physical and cognitive functioning may be also related to other mediating factors, and no cause and effect relationship can be established on the basis of the existing literature. Our findings reflect the results of many studies including two big cohort studies following older adults engaged in different activities (Verghese et al., 2003; Wang et al., 2013).

Wang et al. (2013) who followed for 2.4 years a total of 1,463 Chinese adults without physical and cognitive impairment, aged 65 years at study entry, found that intellectual activities, such as playing cards, chess, or majiang as well as visiting friends and relatives and other social activities, were associated with less cognitive decline. Verghese et al. (2003) who followed up for 5.1 years a total of 469 adults over the age 75 living in the community in the United States and cognitive impairment-free at baseline, also found that reading, playing board games, playing a musical instrument, and ballroom dancing, were associated with a lower risk of dementia. Physical activities were revealed as insignificant in both studies (Verghese et al., 2003; Wang et al., 2013). Therefore, mental exercise may be even more important than physical activity in keeping our brain healthy. These studies confirm that non-digital game playing may have an important protective effect against the development of dementia, and support our findings of the predictive role of playing games on cognitive performance.

Altschul and Deary (2020), who followed up more than 1,000 people to examine the association between playing games and changes in cognitive function from the age of 11 to the age of 70 , and from the age of 70 to 79 , found that those who regularly played non-digital games scored better in general cognitive function, essentially in the memory domain. Controlling for school-age cognitive functioning and other confounders, the authors suggested that playing more games is linked to reduced cognitive decline. The association between playing games and cognitive functions indicates that mental exercise in the form of playing games might help to promote brain stimulation and increase sharper thinking and memory skills. Since games have a highly companionable component, playing games may offer not only mental but also social stimulation for those with dementia. "Exercising" the brain might probably slow down the deterioration of cognitive abilities (Barczak, 2014). Stimulating leisure activities are considered as possible protective factors against cognitive decline in elderly people.

Our analyses highlighted the relationship between the engagement in those activities and depressive symptoms. Depression has been widely recognised as an important risk factor for dementia (Santabárbara et al., 2020). In light of our present findings, it may be that symptomatology connected with depression reduces opportunities for engagement in leisure activities such as playing chess or cards. Those with low mood may rarely choose playing games though, mental and social engagement in diverse leisure activities might contribute to a reduction of stress and improve mental functioning, thereby enhancing the cognitive reserve and supporting the maintenance of brain health. Our study has several limitations. First, the CDT was administered by different raters. Secondly, the results concerning lifestyle factors need to be interpreted with caution, as this data was gathered retrospectively and the recall of previous activities may be biased in individuals with cognitive impairment. In some cases, data was collected on the basis of an interview with the respondent and his/her proxy, which could have improved the validity of reporting. Furthermore, since the data on medical and economic aspects was incomplete, we could not include it in the logistic regression model without a significant reduction in sample size. Considering that our final regression model predicted only about $15 \%$ of the variants, some important predictors of CDT performance could have been missed in our study.

\section{CONCLUSIONS}

The CDT, scored according to the Manos-Wu scoring method can be recommended as a cognitive screening tool for the primary care, which is of utmost importance in patients aged above 75 years. The CDT global score is relatively unaffected by education. Lifestyle factors, such as reading newspapers and playing games, are important in predicting cognitive performance in older adults. Since intellectual activities, both performed individually and in a group, are likely to promote cognitive health, this suggests intervention opportunities.

\section{Conflict of interest}

The authors do not report any financial or personal connections with other persons or organisations that could negatively influence the content of the publication or claim rights to the publication.

\section{Funding/Support and role of the sponsor}

The PolSenior2 study has been funded by Ministry of Health and based on the resources of the National Health Programme 2016-2020 (PL: Narodowy Program Zdrowia - NPZ 2016-2020; Rozporzadzenie Rady Ministrów z dnia 4 sierpnia 2016 r. w sprawie Narodowego Programu Zdrowia na lata 2016-2020; http://dziennikustaw.gov.pl/ DU/2016/1492/1). NPZ, No. 6/5/4.2/NPZ/2017/1203/1257, to Medical University of Gdańsk.

\section{Acknowledgments}

We are grateful to our closest collaborators from PolSenior2 team for fruitful discussions on the paper: dr Hanna Kujawska-Danecka, dr Katarzyna Broczek and prof. Paweł Zagożdżon. 


\section{References}

Ainslie NK, Murden RA: Effect of education on the clock-drawing dementia screen in non-demented elderly persons. J Am Geriatr Soc 1993; 41: 249-252.

Almeida-Meza P, Steptoe A, Cadar D et al.: Is engagement in intellectual and social leisure activities protective against dementia risk? Evidence from the English Longitudinal Study of Ageing. J Alzheimers Dis 2021; 80: 555-565.

Altschul DM, Deary IJ: Playing analog games is associated with reduced declines in cognitive function: a 68-year longitudinal cohort study. J Gerontol B Psychol Sci Soc Sci 2020; 75: 474-482.

Barczak A: Wykształcenie, aktywność umysłowa i socjalna jako czynniki protekcyjne otępienia. Aktualn Neurol 2014; 14: 161-166.

Bledowski P, Mossakowska M, Chudek J et al.: Medical, psychological and socioeconomic aspects of aging in Poland: assumptions and objectives of the PolSenior project. Exp Gerontol 2011; 46: 1003-1009.

Bradford A, Kunik ME, Schulz P et al.: Missed and delayed diagnosis of dementia in primary care: Prevalence and contributing factors. Alzheimer Dis Assoc Disord 2009; 23: 306-314.

Caffarra P, Gardini S, Zonato F et al.: Italian norms for the Freedman version of the Clock Drawing Test. J Clin Exp Neuropsychol 2011; 33: 982-988.

Cullen B, O’Neill B, Evans JJ et al.: A review of screening tests for cognitive impairment. J Neurol Neurosurg Psychiatry 2007; 78: 790-799.

Emek-Savaş DD, Yerlikaya D, Yener GG: Validity, reliability and Turkish norm values of the clock drawing test for two different scoring systems. Turk J Neurol 2018; 24: 143-152.

Fine J: The effect of leisure activity on depression in the elderly: implications for the field of occupational therapy. Occup Ther Health Care 2001; 13: 45-59.

Folstein MF, Folstein SE, McHugh PR: "Mini-mental state." A practical method for grading the cognitive state of patients for the clinician. J Psychiatr Res 1975; 12: 189-198.

von Gunten A, Ostos-Wiechetek M, Brull J et al.: Clock-drawing test performance in the normal elderly and its dependence on age and education. Eur Neurol 2008; 60: 73-78.

Hazan E, Frankenburg F, Brenkel M et al.: The test of time: a history of clock drawing. Int J Geriatr Psychiatry 2018; 33: e22-e30.

Hughes TF, Chang CCH, Vander Bilt J et al.: Engagement in reading and hobbies and risk of incident dementia: the MoVIES project. Am J Alzheimers Dis Other Demen 2010; 25: 432-438.

Kim H, Chey J: Effects of education, literacy, and dementia on the clock drawing test performance. J Int Neuropsychol Soc 2010; 16: 1138-1146.

Klich-Rączka A, Siuda J, Piotrowicz K et al.: Zaburzenia funkcji poznawczych u osób w starszym wieku. In: Mossakowska M, Więcek A, Błędowski P (eds.): Aspekty medyczne, psychologiczne, socjologiczne i ekonomiczne starzenia się ludzi w Polsce. Termedia Wydawnictwa Medyczne, Poznań 2012: 109-121.
Larner AJ (ed.): Cognitive Screening Instruments: A Practical Approach. $2^{\text {nd }}$ ed., Springer International Publishing, Cham 2017.

Lee ATC, Richards M, Chan WC et al.: Association of daily intellectual activities with lower risk of incident dementia among older Chinese adults. JAMA Psychiatry 2018; 75: 697-703.

Lynch JW, Kaplan GA, Shema SJ: Cumulative impact of sustained economic hardship on physical, cognitive, psychological, and social functioning. N Engl J Med 1997; 337: 1889-1895.

Mainland BJ, Shulman KI: Clock Drawing Test. In: Larner AJ (ed.): Cognitive Screening Instruments: A Practical Approach. $2^{\text {nd }}$ ed., Springer International Publishing, Cham 2017.

Mainland BJ, Amodeo S, Shulman KI: Multiple clock drawing scoring systems: simpler is better. Int J Geriatr Psychiatry 2014; 29: 127-136.

Manos PJ: Ten-point clock test sensitivity for Alzheimer's disease in patients with MMSE scores greater than 23. Int J Geriatr Psychiatry 1999; 14: 454-458.

Manos PJ, Wu R: The ten point clock test: a quick screen and grading method for cognitive impairment in medical and surgical patients. Int J Psychiatry Med 1994; 24: 229-244.

Noda S, Shirotsuki K, Nakao M: The effectiveness of intervention with board games: a systematic review. Biopsychosoc Med 2019; 13: 22.

Santabárbara J, Villagrasa B, Gracia-García P: Does depression increase the risk of dementia? Updated meta-analysis of prospective studies. Actas Esp Psiquiatr 2020; 48: 169-180.

Sheikh JI, Yesavage JA: Geriatric Depression Scale (GDS): recent evidence and development of a shorter version. Clin Gerontol 1986; 5: $165-173$.

Shulman KI: Clock-drawing: is it the ideal cognitive screening test? Int J Geriatr Psychiatry 2000; 15: 548-561.

Spenciere B, Alves H, Charchat-Fichman H: Scoring systems for the Clock Drawing Test: a historical review. Dement Neuropsychol 2017; 11: 6-14.

Strauss E, Sherman EMS, Spreen O: A Compendium of Neuropsychological Tests: Administration, Norms, and Commentary. $3^{\text {rd }}$ ed., Oxford University Press, New York 2006.

Verghese J, Lipton RB, Katz MJ et al.: Leisure activities and the risk of dementia in the elderly. N Engl J Med 2003; 348: 2508-2516.

Wang HX, Jin Y, Hendrie HC et al.: Late life leisure activities and risk of cognitive decline. J Gerontol A Biol Sci Med Sci 2013; 68: 205-213.

Wierucki $Ł$, Kujawska-Danecka H, Mossakowska M et al.: Health status and its socio-economic covariates in the older population in Poland - the assumptions and methods of the nationwide, crosssectional PolSenior2 survey. Arch Med Sci 2020. DOI: 10.5114/ aoms.2020.100898.

Wójcik D, Szczechowiak K: Wybrane wersje testu rysowania zegara w praktyce klinicznej - analiza porównawcza ilościowych i jakościowych systemów oceny. Aktualn Neurol 2019; 19: 83-90.

Yamamoto S, Mogi N, Umegaki $\mathrm{H}$ et al.: The clock drawing test as a valid screening method for mild cognitive impairment. Dement Geriatr Cogn Disord 2004; 18: 172-179. 